\title{
Securing China's Weapon-Usable Nuclear Materials
}

\author{
Hui Zhang
}

Project on Managing the Atom in the Belfer Center for Science and International Affairs, Harvard Kennedy School of Government, Cambridge, MA, USA

This article describes the status of China's military and civilian nuclear programs, fissile material production and associated nuclear facilities, and the Chinese nuclear experts and officials' perspectives on the nuclear terrorism threat. It gives details of China's nuclear security practices, attitudes, and regulations, as well as identifying areas of concern. The article recommends ways to strengthen China's nuclear material protection, control, and accounting systems and suggests opportunities for increased international cooperation.

\section{FISSILE MATERIAL STOCKS AND FACILITIES}

As a nuclear weapon state with a large and expanding nuclear power sector, China has stockpiles of both military and civilian nuclear material, especially highly enriched uranium (HEU) and plutonium, and the associated production and storage facilities.

There is considerable uncertainty about China's stockpiles of fissile material. It is estimated that China's military inventory of weapon-grade HEU could be about $16 \pm 4$ tons of HEU and $1.8 \pm 0.5$ tons of weapon-grade for weapons. ${ }^{1}$

China has produced HEU for weapons at two facilities: Lanzhou gaseous diffusion plant (GDP), which began operating in January 1964; and Heping

Received 19 July 2013; accepted 2 November 2013.

The author is grateful to those Chinese nuclear experts who participated in interviews. The author also would like to thank Matthew Bunn and Martin Malin for helpful discussions and the Carnegie Corporation of New York and the John D. and Catherine MacArthur Foundation for financial support of this work.

Address correspondence to Hui Zhang, Belfer Center for Science and International Affairs, Harvard Kennedy School of Government, 79 John F. Kennedy Street, Cambridge, MA 02138, USA. E-mail: hui_zhang@harvard.edu 
GDP, a "Third Line" facility that began operating in 1975. The Lanzhou and Heping GDPs stopped production of HEU in 1979 and 1987, respectively. ${ }^{2}$

China has produced plutonium for weapons at two nuclear complexes: The first is the Jiuquan Atomic Energy Complex. This site includes China's first plutonium reactor, which began operation in 1966, and the associated reprocessing facilities. The second is the Guangyuan plutonium production complex. The reactor began operation in 1973. Both the Jiuquan and Guangyuan reactors stopped plutonium production in 1984 and 1989 respectively. All these military production facilities have been closed, converted, or are being decommissioned. ${ }^{3}$

It is estimated that perhaps less than half of China's military stocks of fissile materials could be contained in its nuclear warheads. The rest of the material could be located at a small number of sites including the Jiuquan and Guangyuan plutonium production complexes which conduct HEU and plutonium processing, warhead component production, and weapon assembly; the China Academy of Engineering Physics which conducts research, development and design of nuclear weapons; and at storage facilities of fissile materials (see Table 1). Chinese non-weapon uses of HEU and plutonium are very limited. China's nuclear-power submarines are fueled with low-enriched uranium (LEU).

\section{Military Stock}

China has an estimated total inventory of approximately 170 nuclear warheads including about 110 operationally deployed nuclear missiles, and 60 warheads stored for its submarine-launched ballistic missiles (SLBMs), and bombers. ${ }^{4}$

It has been reported that China has a highly centralized storage and handling system for warheads managed by 22 Base under the Second Artillery Corps. ${ }^{5}$ Most of the Chinese warheads are stored at the 22 Base and a very limited number of warheads are in storage at six missile bases. The central warhead storage complex is in Taibai Mountain. ${ }^{6}$ The 22 Base uses advanced physical protection systems including real time video and infrared monitoring, fingerprinting, temperature and humidity controls, and a computerized warhead accounting system. ${ }^{7}$

\section{Civilian Stock}

Civil use of HEU in China is limited. China's Experimental Fast Reactor (CEFR), which reached criticality in July 2010, had a first loading of almost $240 \mathrm{~kg}$ of HEU (64.4\% uranium-235), provided by Russia. The CEFR eventually will use mixed oxide fuel (MOX), as will China's planned future fast reactors. China has a number of HEU-fueled research reactors (see Table 2). 
Table 1: China's institutions and nuclear facilities associated with fissile material production.

Nuclear weapon design and manufacture facilities

\begin{tabular}{|c|c|}
\hline $\begin{array}{l}\text { China Academy of Engineering } \\
\text { Physics (CAEP), Mianyang, } \\
\text { Sichuan }\end{array}$ & $\begin{array}{l}\text { Research, development and design of } \\
\text { nuclear weapons }\end{array}$ \\
\hline $\begin{array}{l}\text { Jiuquan Atomic Energy Complex, } \\
\text { Yumen, Gansu (Plant 404) }\end{array}$ & $\begin{array}{l}\text { Former plutonium production facility. } \\
\text { Conducts HEU and plutonium } \\
\text { processing; warhead component } \\
\text { production; and weapon assembly. }\end{array}$ \\
\hline $\begin{array}{l}\text { Guangyuan plutonium prod } \\
\text { complex, Guangyuan, Sich } \\
\text { (Plant } 821 \text { ) }\end{array}$ & $\begin{array}{l}\text { Former plutonium production facility. } \\
\text { clear if conducts plutonium processi } \\
\text { warhead production. }\end{array}$ \\
\hline
\end{tabular}

Plutonium production reactors

\begin{tabular}{|c|c|}
\hline $\begin{array}{l}\text { Jiuquan reactor at Plant } 404 \\
\text { Guangyuan reactor at Plant } 821\end{array}$ & $\begin{array}{l}\text { Operated in 1966-1984 } \\
\text { Operated 1973-1989; being } \\
\text { decommissioned. }\end{array}$ \\
\hline \multicolumn{2}{|c|}{ Reprocessing plants } \\
\hline $\begin{array}{l}\text { Jiuquan intermediate } \\
\text { reprocessing plant (small) at } \\
\text { Plant } 404\end{array}$ & Operated 1968-early 1970s. \\
\hline $\begin{array}{l}\text { Jiuquan military reprocessing } \\
\text { plant (large) at Plant } 404\end{array}$ & Operated 1970-1984 \\
\hline $\begin{array}{l}\text { Guangyuan reprocessing plant at } \\
\text { Plant } 821\end{array}$ & Operated 1976-1991 \\
\hline $\begin{array}{l}\text { Pilot reprocessing plant at Plant } \\
404\end{array}$ & $\begin{array}{l}\text { Civilian; operational since December } \\
2010\end{array}$ \\
\hline \multicolumn{2}{|c|}{ Enrichment plants } \\
\hline $\begin{array}{l}\text { Lanzhou Gaseous Diffusion Plant } \\
\text { (GDP) (Plant 504), Lanzhou, } \\
\text { Gansu }\end{array}$ & $\begin{array}{l}\text { Former military facility; shut down; began } \\
\text { operation in } 1964 \text { and ended HEU } \\
\text { production in } 1979 \text {. }\end{array}$ \\
\hline $\begin{array}{l}\text { Heping GDP (Plant 814), Heping, } \\
\text { Sichuan }\end{array}$ & $\begin{array}{l}\text { Former military facility; began operation } \\
\text { in } 1975 \text { and ended HEU production in } \\
\text { 1987. Producing LEU for naval reactors? }\end{array}$ \\
\hline $\begin{array}{l}\text { Lanzhou CEP (Plant 504), Lanzhou, } \\
\text { Gansu }\end{array}$ & $\begin{array}{l}\text { Operational since } 2001 \text {; producing LEU } \\
\text { for civilian use. }\end{array}$ \\
\hline Hanzhong CEP, Shaanxi & $\begin{array}{l}\text { Operational since 1996; producing LEU } \\
\text { for civilian use; under IAEA safeguards. }\end{array}$ \\
\hline
\end{tabular}

Since 2007, several have been shut down or converted to LEU. Now the major operational facilities include two miniature neutron source reactors (MNSR) (approximately $1 \mathrm{~kg}$ of 90\% uranium-235 in each), one zero-power fast critical reactor (90\% uranium-235, $0.05 \mathrm{kWt})$, and one PPR pulsed reactor $(20 \%$ uranium-235, $1 \mathrm{MWt}$ ).

China has decided to shut down its MNSRs and build new LEU fueled reactors. In September 2010, China Atomic Energy Authority (CAEA) and the U.S. Department of Energy (DOE) signed an agreement to convert a miniature research reactor in China from HEU to LEU fuel. ${ }^{8}$ The project was implemented 
Table 2: China's research reactors.

\begin{tabular}{|c|c|c|c|}
\hline Reactor & Operator & Characteristics & Status \\
\hline $\begin{array}{l}\text { China Experimental } \\
\text { Fast Reactor (CEFR) }\end{array}$ & $\begin{array}{l}\text { China Institute of } \\
\text { Atomic Energy } \\
\text { (CIAE), Beijing }\end{array}$ & $\begin{array}{l}\text { FBR, } 64.4 \% \text { HEU, } 65 \\
\text { MWt/25MWe }\end{array}$ & $\begin{array}{l}\text { Operational since } \\
\text { July } 2011\end{array}$ \\
\hline $\begin{array}{l}\text { Zero Power Fast Critical } \\
\text { Reactor }\end{array}$ & $\begin{array}{l}\text { Nuclear Power Institute } \\
\text { of China (NPIC), } \\
\text { Chengdu, Sichuan }\end{array}$ & $\begin{array}{r}\text { Critical fast, } 90 \% \\
\text { HEU, } 0.05 \mathrm{kWt}\end{array}$ & Operational \\
\hline PPR Pulsing Reactor & NPIC, Chengdu & $\begin{array}{l}\text { Pool, 20\% HEU, } 1 \\
\text { MWt }\end{array}$ & Operational \\
\hline MNSR-SZ & $\begin{array}{l}\text { Shenzhen Univ., } \\
\text { Guangdong }\end{array}$ & $\begin{array}{l}\text { Tank in pool, LW, } \\
90 \% \text { HEU, } 30 \mathrm{kWt}\end{array}$ & $\begin{array}{l}\text { Operational (to be } \\
\text { converted) }\end{array}$ \\
\hline MNSR-IAE & CIAE, Beijing & $\begin{array}{l}\text { Tank in pool, LW, } \\
90 \% \text { HEU, } 27 \mathrm{kWt}\end{array}$ & $\begin{array}{l}\text { Operational (to be } \\
\text { converted under } \\
\text { U.S.-China } \\
\text { cooperation) }\end{array}$ \\
\hline HFETR & NPIC, Chengdu & $\begin{array}{l}\text { Tank, LW, LEU, } 125 \\
\text { MWt }\end{array}$ & $\begin{array}{l}\text { Converted in } 2007 \text {, } \\
\text { operational }\end{array}$ \\
\hline MJTR & NPIC, Chengdu & $\begin{array}{l}\text { Pool, LW, LEU, } 5 \\
\text { MWt }\end{array}$ & $\begin{array}{l}\text { Converted in } 2007 \text {, } \\
\text { operational }\end{array}$ \\
\hline MNSR-SD & $\begin{array}{l}\text { Research Institute of } \\
\text { Geological Science, } \\
\text { Jinan, Shandong }\end{array}$ & $\begin{array}{l}\text { Tank in pool, LW, } \\
90 \% \mathrm{HEU}, 33 \mathrm{kWt}\end{array}$ & $\begin{array}{l}\text { Shut down } \\
\text { (reportedly in } \\
\text { December 2010) }\end{array}$ \\
\hline MNSR-SH & $\begin{array}{l}\text { Shanghai Institute. For } \\
\text { Measurement and } \\
\text { Testing Technology, } \\
\text { Shanghai }\end{array}$ & $\begin{array}{l}\text { Tank in pool, LW, } \\
90 \% \text { HEU, } 30 \mathrm{kWt}\end{array}$ & Shut down in 2007 \\
\hline $\begin{array}{l}\text { HFETR Critical } \\
\text { Assembly }\end{array}$ & NPIC, Chengdu & $\begin{array}{l}\text { Critical assembly, } \\
\text { LW, LEU, } 0 \text { KWt }\end{array}$ & $\begin{array}{l}\text { Converted in } 2007 \text {, } \\
\text { reportedly shut } \\
\text { down later. }\end{array}$ \\
\hline $\begin{array}{l}\text { Fast Neutron Critical } \\
\text { Assembly }\end{array}$ & CIAE, Beijing & $0 \mathrm{kWt}$, likely HEU & Operational \\
\hline HWRR & CIAE, Beijing & LEU, $15 \mathrm{MWt}$ & Operational \\
\hline SPR & CIAE, Beijing & Pool, LEU, 3.5 MW & Operational \\
\hline $\begin{array}{l}\text { China Advanced } \\
\text { Research Reactor } \\
\text { (CARR) }\end{array}$ & CIAE, Beijing & $\begin{array}{l}\text { Tank in pool, LW, } \\
19.75 \% \text { LEU, } 60 \\
\text { MWt }\end{array}$ & $\begin{array}{l}\text { First Critical in May } \\
2010\end{array}$ \\
\hline NHR-5 & $\begin{array}{l}\text { Tsinghua University, } \\
\text { Beijing }\end{array}$ & $\begin{array}{l}\text { Heating supply } \\
\text { reactor, LEU, } 5 \\
\text { MWt }\end{array}$ & Operational \\
\hline HTR-10 & $\begin{array}{l}\text { Tsinghua University, } \\
\text { Beijing }\end{array}$ & $\begin{array}{l}\text { High Temperature } \\
\text { Gas-Cooled } \\
\text { Reactor, coated } \\
\text { particle fuels, LEU, } \\
10 \mathrm{MWt}\end{array}$ & Operational \\
\hline ESR-901 & $\begin{array}{l}\text { Tsinghua University, } \\
\text { Beijing }\end{array}$ & $\begin{array}{l}\text { Pool, 2-cores, } 1 \mathrm{MWt} \\
\text { 19.75\% LEU }\end{array}$ & $\begin{array}{c}\text { Critical in 1964, } \\
\text { operational }\end{array}$ \\
\hline
\end{tabular}

Notes. Ministry of Environmental Protection, National Nuclear Safety Administration, Comprehensive Safety Inspection Report on Civilian Nuclear Facilities, 2012, <http://wwW.mep.gov.cn/zjyj/201206/W020120615619308262677.pdf >; NTI, Civilian HEU: China <http://www.nti.org/analysis/articles/civilian-heu-china/>; IAEA Research Reactor, data at http://nucleus.iaea.org/RRDB/RR/ReactorSearch.aspx. 


\section{Zhang}

in 2013. China is willing to assist other countries in converting their research reactors by utilizing the expertise and experience gained from the relevant cooperation with the United States. China's use of HEU for research reactors in the future would be insignificant.

China produced no civilian plutonium until it operated a pilot reprocessing plant at Jiuquan nuclear complex in 2010. The pilot plant had a production capacity of $50 \mathrm{tHM} /$ year. After operations began on December 21, 2010, in its annual IAEA INFCIRC/549 report of civilian plutonium holdings for 31 December 2010, China declared a stock of $13.8 \mathrm{~kg}$ of separated plutonium "in product stores at reprocessing plants." In September 2013, China reported that on 31 December 2012 its total civilian stock of separated plutonium was $13.8 \mathrm{~kg}$, indicating that there was no additional plutonium produced between 2010 and 2012, and that the plant operated for only 10 days and below capacity. $^{10}$

In recent years, the China National Nuclear Corporation (CNNC) has been negotiating with France's Areva to build a commercial reprocessing plant (800 tHM/year). Recently the CNNC has discussed plans to build a medium-scale commercial reprocessing plant (200 tHM/year) by 2020 and a larger one (800 tHM/year) between 2025 and $2030 .^{11}$

A pilot MOX fuel fabrication plant (with a capacity of $0.5 \mathrm{MT} / \mathrm{year}$ ) is now under construction near the pilot reprocessing plant. It will supply the first MOX fuel to China's experimental fast reactor. The plutonium for the MOX fuel will come from the pilot reprocessing plant. Moreover, the CNNC signed an agreement with Russia in 2009 with an intention to purchase two Russian 800 MWe BN-800 fast breeder reactors (FBR). The CNNC also plans to build a series of commercial FBRs by $2032 .{ }^{12}$ Significant quantities of separated plutonium will be produced in civilian sector once these reprocessing plants and FBRs are in operation.

In addition, by October 2013, China had 17 operating power reactors with an aggregate installed capacity of about $14 \mathrm{GWe}$, and an additional 29 reactors under construction, making the Chinese nuclear industry by far the fastest growing in the world. China plans to install a total nuclear capacity of $40 \mathrm{GWe}$ by 2015 and 58 GWe by $2020 .{ }^{13}$ However, all are LEU fueled reactors.

\section{CHINESE ASSESSMENT OF THE RISK OF NUCLEAR TERRORISM}

China's government emphasized in its national defense white paper published in 2000 that, "China's nuclear force is under the direct command of the Central Military Commission (CMC)." The document emphasized that China is extremely cautious and responsible in the management of its nuclear weapons, and has established strict rules and regulations and taken effective measures to ensure the safety and security of its nuclear weapons."14 
After the U.S. terrorist attacks on September 11, 2001 (9/11), Chinese experts began to analyze the risks and discuss the management of nuclear and radiological terrorism. In 2003, the China Academy of Engineering launched a risk assessment project involving experts from various national nuclear agencies including National Nuclear Safety Administration (NNSA), China Institute of Atomic Energy, the China National Nuclear Corporation, and the China Academy of Engineering Physics. In 2005 this led to an authoritative report "Management of Nuclear and Radiological Terrorism Incidents."15

In 2006, the CAEA and the IAEA established a "CAEA-IAEA Joint Training Center on Nuclear Safeguards and Security" with an aim to strengthen the training capability on nuclear safeguards and security. In January 2011, China and the United States signed the "Memorandum of Understanding for Cooperation in Establishing a Center of Excellence on Nuclear Security" (COE). The COE broke ground on 29 October 2013 and should be completed in $2015 .{ }^{16}$ The center will serve as a forum for exchanging technical information, sharing best practices, developing training courses, and promoting technical collaborations to enhance nuclear security in China and throughout Asia.

At the 2012 Nuclear Security Summit, Chinese president Hu Jintao emphasized that, "In the future, China will [take further] nuclear security measures, make sure [of] the security of its own nuclear materials and facilities, [and] improve ... overall nuclear security." 17 Beijing has recently been increasing its concerns about the threats of terrorism. ${ }^{18}$ Its recent national defense white paper states, "China still faces multiple and complicated security threats and challenges." The threats are described as the "three forces"-terrorism, separatism and extremism—-which are said to be on the rise. ${ }^{19}$ Concern also has increased among Chinese experts about the threat of smuggling fissile materials or weapons into China. ${ }^{20}$ China has borders with Central Asia and Pakistan, where there is a high level of international terrorist activity and there is a cause for higher levels of concern.

Chinese experts, scholars, and officials widely accept four main types of nuclear terrorism: 1) theft, seizure, and the explosion of nuclear weapons; 2) theft, smuggling, purchase, and other means of acquiring nuclear materials, and manufacturing and explosion of a nuclear device; 3) sabotage of nuclear facilities; and 4) radiological dispersal device or "dirty bomb." ${ }^{21}$ But many Chinese nuclear experts do not see the terrorism threat as realistic or urgent. They argue it would be extremely difficult for terrorists to acquire the required fissile materials or a nuclear weapon within China due to China's strict security system for its very limited weapon-usable nuclear materials and nuclear arsenal.

Many Chinese experts believe it is implausible (if not impossible) for Chinese nuclear weapons to be stolen because China's arsenal is relatively small, tightly monitored, and guarded by heavily armed forces. ${ }^{22}$ Moreover, most Chinese warheads are stored deep underground in remote mountains and the locations are kept highly secret and would be very difficult for outsiders to access. 
Chinese nuclear weapon experts believe that terrorists do not have the capabilities to produce highly enriched uranium and separated plutonium. However, once they acquire enough fissile materials through theft, smuggling, purchase, and other means, they would be able to manufacture and detonate a crude nuclear weapon. In particular, with enough HEU, a gun-type bomb is well within the capabilities of a sophisticated terrorist group. While Chinese experts see HEU as the preferred material for terrorists, they agree that any grade of plutonium, including reactor-grade, could be used to build an implosion bomb. ${ }^{23}$

Chinese nuclear experts believe that the probability of terrorists getting access to fissile materials inside China and manufacturing a crude bomb is very low. They argue that the technologies necessary for manufacturing, delivering, and detonating a weapon are very difficult for Chinese terrorists to obtain. However, experts are not able to rule out the possibility of terrorists smuggling a nuclear weapon or nuclear materials from outside of China. ${ }^{24}$

As the number of China's nuclear power plants is rapidly increasing, the risk of sabotage of civilian nuclear facilities, particularly a nuclear power plant, is seen as becoming more plausible. ${ }^{25}$ Also, the Fukushima accident may increase the interest of terrorists in targeting power reactors in China. But experts perceive the risk of a major radioactive release resulting from a terrorist sabotage of a nuclear power plant as very low because the terrorists lack the means or tools to conduct such attacks and China's current security system should be good enough to prevent them. ${ }^{26}$

Instead, Chinese experts believe the most realistic threat of nuclear terrorism in China is from a radiological dispersal device or "dirty bomb." ${ }^{27}$ One reason for this concern is that China has many radioactive sources distributed widely, and also many orphan and spare sources. Moreover, there is a weaker control and management system for these distributed sources. ${ }^{28}$ Based on a survey in 2002 by the State Bureau of Environmental Protection, the Ministry of Public Health, and the Ministry of Public Security, China had a total of 63,721 radioactive sources and 8,312 users, including hospitals, industry, agriculture, research, and education departments. In addition, approximately 13,000 spent radioactive sources were awaiting disposal. ${ }^{29}$ As one nuclear expert estimated, approximately 2,000 radioactive sources were completely uncontrolled due to problems in the management system. ${ }^{30}$ While the government makes efforts to find orphan sources, about 1000 radioactive sources are believed to be lost. ${ }^{31}$

Some experts view China's commitments to upgrading nuclear security as more an international requirement than as a response to a serious threat. Some argue that nuclear terrorism may be a problem to the United States, but it may be not so urgent for China. ${ }^{32}$ China is also facing the challenge of complacency that exists among a significant number of senior nuclear experts and nuclear industries. They believe that China already has strict nuclear 
security systems that have worked well and "free of accident" over past 50 years. One nuclear expert from $\mathrm{CNNC}$ has pointed out that when it comes to nuclear materials the record shows "no[t] one gram missed and no[t] one item disappeared" over the last 50 years. ${ }^{33}$

In addition, some argue that the stricter the security standards employed, the higher the capital and operating costs. In particular, for bulk-processing facilities (e.g., fuel fabrication plants, reprocessing facilities, and enrichment plants) limited financial resources have often caused operators to give safety and security a low priority when allocating resources. Moreover, security is given even a lower priority than safety. In some cases, the guards turn off the detectors at the portal of enrichment facilities to avoid wear and early replacement. ${ }^{34}$ Also, some doubt whether it is worth the money and time to have a stricter security system.

The rapid growth of the nuclear industry has created a serious shortage of adequately trained security personnel and other necessary staff. As more employees are hired from non-nuclear fields, the safety and security culture is further diluted. As plants have converted from military to civilian missions, a culture of secrecy still exists and operators are not willing to share information about problems with outsiders, including inspectors. ${ }^{35}$

To overcome these challenges, the operators must believe that a terrorist threat is real. The possibility of insider theft of nuclear materials cannot be ruled out, particularly as China increasingly develops into a market-oriented society with an associated increase in corruption. Indeed, some Chinese experts worried that the big changes in China's society over recent decades could increase criminal activity thus increasing the likelihood for attempted thefts and smuggling. ${ }^{36}$ Many experts believe that the more pervasive corruption becomes, the higher is the potential for the theft of materials and the need for increased security. ${ }^{37}$

The risk of an insider threat is perhaps the most challenging because the insiders have authorized access to nuclear material areas and understand the operations, rules, policies, and regulations concerning nuclear materials. ${ }^{38}$ Some insiders are highly trained in handling nuclear materials and have the opportunity to understand how to defeat safety and security systems. One or more of these individuals could work with other on-site personnel or outsiders and take advantage of access to perform acts of theft or sabotage and potentially aid terrorists.

HEU and separated plutonium in China's civilian sector could be more vulnerable to insiders. In particular, some Chinese nuclear experts are aware of the threat of fresh HEU or spent HEU fuel at research reactors. ${ }^{39}$ These reactors are located at institutes that are not as well controlled and guarded as the military sites because of a shortage of funding. Moreover, the security and control system at some old facilities is of a lower level than that of new ones. 
Separated plutonium at China's civilian pilot reprocessing plant poses another challenge. The pilot plant began construction in 1995 and was not based on security-by-design. It shares some facilities with the previous military reprocessing plant which were not designed using a modern material control and accountability (MC\&A) system. Consequently, the accounting system might not be adequate for the new mission. Indeed, one problem with the plant is that the values for the material unaccounted for (MUF) are higher than is considered acceptable. ${ }^{40}$ Chinese nuclear experts are concerned that, the plutonium products could be a target for nuclear terrorists.

\section{CHINA'S NUCLEAR SECURITY: PROGRESS AND CHALLENGES}

\section{Legal Framework}

Since the mid-1980s, China has issued a number of regulations, rules, and technical guidelines regarding the security of nuclear and radioactive materials and nuclear facilities. In China, there are several categories of laws and regulations: Statutory law requiring approval by the National People's Congress, State Council law and regulations, departmental rules, and regulator's guidance or documents. ${ }^{41}$ China does not yet have a statutory law for nuclear development, safety and security; it is still drafting the Atomic Energy Law.

China has joined nearly all the international legal instruments relevant to nuclear security, including the 2005 amendment of the 1980 Convention on the Physical Protection of Nuclear Material and the International Convention for the Suppression of Acts of Nuclear Terrorism. It is also bound by United Nations Security Council Resolution 1540. Fulfilling those international obligations is a major driver of the development of China's nuclear security. China has improved and built up its legal system in some areas related to nuclear security, including nuclear export control, control of radioactive materials and their shipments, and nuclear emergency response. ${ }^{42}$ However, regulations and rules on the security of nuclear materials and facilities have not been kept up to date.

Currently, the only major legal instrument on fissile material control is the Regulations for Control of Nuclear Materials, issued in 1987. ${ }^{43}$ Based on this regulation, China issued in 1990 the "Rules" for Implementation of the Regulations on Nuclear Materials Control. ${ }^{44}$ This is also the only rule governing nuclear material control.

When both the 1987 Regulation and 1990 Rules were issued, all of China's weapon-usable fissile materials were produced by its military production facilities and were used almost solely for weapons purposes (a very small portion for HEU-fuel reactors), so the 1987 Regulation and 1990 Rules may still be applied to China's military nuclear materials and nuclear facilities. 
In 2008, the NNSA issued the Nuclear Facility Physical Protection Guidelines that updated the guidelines for physical protection measures for all civilian nuclear facilities. ${ }^{45}$ However, it is not clear whether the measures for the military nuclear facilities were updated.

The CAEA is responsible for the security of China's nuclear materials and for adopting a licensing system. To become licensed, an operator must establish an effective nuclear material protection, control, and accounting (MPC\&A) system that meets the regulatory guidelines. Inspection activities include verifying the integrity of accounting records, physical inventory changes, measurement and quality control systems, material balance, and effectiveness and reliability of physical protection measures. If a facility is found in violation of these regulations, it could be punished by warning, penalty, or revoking its license, depending on the seriousness of the violation.

It should be noted that these regulations and rules on security of nuclear materials and facilities were issued before the 9/11 attacks, and do not mention the threat of nuclear terrorism. These regulations should be updated to reflect the potential threats posed after the $9 / 11$ attacks.

\section{Physical Protection System}

China's management of nuclear material security and physical protection is mainly based on the 1990 Rules and the IAEA related recommendations (INFCIRC/225 Rev.4). All facility operators are required to establish a facility level organization in charge of the security of facilities and nuclear materials. Similar to the IAEA recommendations on physical protection of nuclear materials, China divides its protection requirements for nuclear material into three categories based on type, quantity, and harmfulness of the nuclear material (see Tables 3 and 4). ${ }^{46}$

The most updated and detailed documents on physical protection of China's nuclear facilities can be read from the 2008 NNSA guidelines of "Nuclear Facility Physical Protection.” Before the 9/11 attacks, China's nuclear facilities were mainly designed to protect from natural disasters or accidents. However, since the 9/11 attacks, China has made substantial changes in its nuclear security approaches, such as protecting nuclear facilities against design basis threat (DBT), including both outsider and insider adversaries. The 2008 guidelines also require specific physical protection measures for three categories of nuclear facilities in China (see Tables 5 and 6). The protection measures are ranked according to the relative attractiveness of the stored material, the nature of nuclear materials and facilities, and potential consequences of theft. All Chinese civilian nuclear facilities should meet the 2008 Guidelines requirements. Many old facilities have been upgrading their security systems. 
60 Zhang

Table 3: Categorization of fissile materials in China.

\begin{tabular}{|c|c|}
\hline Category I & $\begin{array}{l}\text { - } 2 \mathrm{~kg} \text { or more unirradiated plutonium } \\
-5 \mathrm{~kg} \text { or more HEU }\end{array}$ \\
\hline Category II & $\begin{array}{l}\text { - Less than } 2 \mathrm{~kg} \text { but more than } 10 \mathrm{~g} \text { unirradiated } \\
\text { plutonium } \\
\text { - Less than } 5 \mathrm{~kg} \text { but more than } 1 \mathrm{~kg} \text { HEU } \\
\text { - } 20 \mathrm{~kg} \text { or more unirradiated uranium-235 ( } 10 \% \text { but } \\
\text { less than } 20 \% \text { enriched) } \\
\text { - } 300 \mathrm{~kg} \text { or more unirradiated uranium-235 (enriched } \\
\text { to less than } 10 \% \text {; not including natural and } \\
\text { depleted uranium) }\end{array}$ \\
\hline Category III & $\begin{array}{l}\text { - } 10 \mathrm{~g} \text { or less unirradiated plutonium; } \\
\text { - } 1 \mathrm{~kg} \text { or less but more than } 10 \mathrm{~g} \mathrm{HEU} \\
\text { - } 1 \mathrm{~kg} \text { or more but less than } 20 \mathrm{~kg} \text { unirradiated } \\
\text { uranium-235 (10\% but less than } 20 \% \text { enriched) } \\
\text { - } 10 \mathrm{~kg} \text { or more but less than } 300 \mathrm{~kg} \text { unirradiated } \\
\text { uranium-235 (enriched to less than } 10 \% \text {; not } \\
\text { including natural and depleted uranium) }\end{array}$ \\
\hline
\end{tabular}

Note. Rules for Implementation of the Regulations on Nuclear Materials Control of the People's Republic of China, National Nuclear Safety Administration (NNSA), the Ministry of Energy, and the Commission of Science, Technology, and Industry for National Defense, September 25, 1990. Chinese version is available at CAEA website <www: http://www.caea.gov.cn/n16/n1130/77224.html>. Note that the 1990 Rules do not cover other materials, such as U-233.

Table 4: Physical protection measures for fissile materials at fixed sites.

- At least two complete, reliable physical barriers; vault
Or special security container for storage
- A technical protection system with alarm and
monitoring installations
- 24-hour armed guard
- Special pass for all people entering the site
- Strict registration control and required escort for all
Off-site personnel
- Vault access controlled by "double men and double
lock" system
- Two physical barriers with one that is complete and
reliable; a "strong room" or "solid container" type
- Alorage area
- Provided in vital areas
- 24-hour armed guards or specially assigned persons
- Special pass for all people entering the site
- One complete and reliable physical barrier
- Specially assigned persons for watching or letting
nuclear material be placed in security containers

Note. Rules for Implementation of the Regulations on Nuclear Materials Control of the People's Republic of China, the National Nuclear Safety Administration (NNSA), the Ministry of Energy, and the Commission of Science, Technology, and Industry for National Defense, September 25, 1990. Chinese version is available at CAEA website <www: http://www.caea.gov.cn/n16/n1130/77224.html>. 
Table 5: Three categories of civilian nuclear facilities in China.

\begin{tabular}{|c|c|c|}
\hline Category I & Category II & Category III \\
\hline $\begin{array}{l}\text { Facilities containing } \\
\text { category I nuclear } \\
\text { materials }\end{array}$ & $\begin{array}{l}\text { Facilities containing } \\
\text { category II nuclear } \\
\text { materials }\end{array}$ & $\begin{array}{l}\text { Facilities containing } \\
\text { category III nuclear } \\
\text { materials }\end{array}$ \\
\hline $\begin{array}{l}100 \mathrm{MW}(\mathrm{th}) \text { reactors or } \\
\text { larger }\end{array}$ & 2-100 MW(th) reactors & $\begin{array}{l}\text { Less than } 2 \text { MW(th) } \\
\text { reactors }\end{array}$ \\
\hline \multirow[t]{2}{*}{$\begin{array}{l}\text { Spent fuel pools with some } \\
\text { new discharged fuels } \\
\text { and the total } \\
\text { radioactivity greater } \\
\text { than } 10^{17} \text { Bq cesium-137 }\end{array}$} & $\begin{array}{l}\text { Middle-level liquid and } \\
\text { high-level solid nuclear } \\
\text { waste storage and } \\
\text { processing facilities }\end{array}$ & $\begin{array}{l}\text { Low-level liquid and } \\
\text { middle-level solid } \\
\text { nuclear waste storage } \\
\text { and processing facilities }\end{array}$ \\
\hline & $\begin{array}{l}\text { Spent fuel pools requiring } \\
\text { active cooling systems }\end{array}$ & \multirow{3}{*}{$\begin{array}{l}\text { Facilities where direct } \\
\text { exposure dose rate } \\
\text { without shielding } \\
\text { measures is larger than } \\
100 \text { mGy/h at } 1 \text { meter } \\
\text { distance }\end{array}$} \\
\hline $\begin{array}{l}\text { Spent fuel reprocessing } \\
\text { facilities }\end{array}$ & $\begin{array}{l}\text { and not covered by } \\
\text { category I case }\end{array}$ & \\
\hline \multirow[t]{2}{*}{$\begin{array}{l}\text { High-level liquid nuclear } \\
\text { waste storage and } \\
\text { processing facilities }\end{array}$} & \multirow{3}{*}{$\begin{array}{l}\text { Facilities where any on-site } \\
\text { criticality accidents } \\
\text { without control measures } \\
\text { can pose impacts } \\
\text { beyond } 0.5 \mathrm{~km} \text { from the } \\
\text { facility perimeter }\end{array}$} & \\
\hline & & \multirow{3}{*}{$\begin{array}{l}\text { Facilities where any on-site } \\
\text { criticality accidents } \\
\text { without control measures } \\
\text { can pose impacts within } \\
0.5 \mathrm{~km} \text { from the facility } \\
\text { perimeter }\end{array}$} \\
\hline \multirow[t]{3}{*}{ Others facilities } & & \\
\hline & Others facilities & \\
\hline & & Others facilities \\
\hline
\end{tabular}

Notes. Ministry of Environmental Protection, National Nuclear Safety Administration, "Nuclear Facility Physical Protection Guidelines," 2008, HDA501/502. Note that guidelines do not contain an exhaustive list, so they could apply to facilities that are not explicitly included in the list.

However, the 2008 Guidelines lack clearly defined standards for each nuclear facility. Facility operators typically design their own DBTs on a caseby-case basis according to a number of factors, including the socioeconomic situation in the surrounding area. ${ }^{47}$ China's current DBT for nuclear facilities may not include extreme adversary scenarios, such as a 9/11-type attack. ${ }^{48}$ As the director of the NNSA, Li Ganjie, has noted, under the existing DBT, civilian facilities might be insufficient to repel attacks from larger and better-organized terrorist groups, or attacks involving powerful weapons. ${ }^{49}$ Some experts argue that China has been unable to construct a more systematic and rigorous approach to DBTs mainly because it lacks familiarity with the necessary concepts and processes. ${ }^{50}$

China applies modern concepts of Physical Protection System (PPS) to its nuclear facilities, e.g., modern technology and techniques for the detection function of its PPS, including microwave detectors, active infrared sensors, and video motion detectors and a number of technical measures to the delay function at nuclear facilities, including double fences with intrusion detectors and 
Table 6: Physical protection measures for civilian nuclear facilities in China.

\begin{tabular}{|c|c|c|}
\hline Category I & Category II & Category III \\
\hline \multirow{2}{*}{$\begin{array}{l}\text { 24-hour armed guard at } \\
\text { access points in the } \\
\text { vital, controlled and } \\
\text { protected areas. }\end{array}$} & \multirow{2}{*}{$\begin{array}{l}24 \text { hour armed guard at } \\
\text { access points in } \\
\text { controlled and } \\
\text { protected areas. }\end{array}$} & $\begin{array}{c}\text { Facilities located in } \\
\text { controlled area }\end{array}$ \\
\hline & & \multirow{2}{*}{$\begin{array}{l}\text { Communication and } \\
\text { monitoring system at all } \\
\text { entrances and access } \\
\text { areas }\end{array}$} \\
\hline $\begin{array}{l}\text { Alarm and monitoring } \\
\text { system at all entrances } \\
\text { and access areas }\end{array}$ & $\begin{array}{l}\text { Alarm and monitoring } \\
\text { system at all entrances } \\
\text { and access areas }\end{array}$ & \\
\hline $\begin{array}{l}\text { Required pass or badge } \\
\text { for authorized } \\
\text { personnel and vehicles }\end{array}$ & $\begin{array}{l}\text { Required pass or badge } \\
\text { for authorized } \\
\text { personnel and vehicles }\end{array}$ & $\begin{array}{l}\text { Required pass or badge } \\
\text { for authorized } \\
\text { personnel and vehicles }\end{array}$ \\
\hline \multirow{2}{*}{$\begin{array}{l}\text { Strict registration control } \\
\text { and required escort for } \\
\text { all off-site personnel } \\
\text { and vehicles }\end{array}$} & \multirow{2}{*}{$\begin{array}{l}\text { Strict registration control } \\
\text { and required escort for } \\
\text { all off-site personnel } \\
\text { and vehicles }\end{array}$} & $\begin{array}{l}\text { Emergency power } \\
\text { backup system }\end{array}$ \\
\hline & & $\begin{array}{l}\text { An office with security } \\
\text { personnel on duty }\end{array}$ \\
\hline $\begin{array}{l}\text { A "two man and } \\
\text { double-lock" rule for } \\
\text { the vital area }\end{array}$ & $\begin{array}{l}\text { Radioactive material } \\
\text { detection systems } \\
\text { installed at access to } \\
\text { the protected area }\end{array}$ & \\
\hline \multirow{2}{*}{$\begin{array}{l}\text { Radioactive material } \\
\text { detection systems } \\
\text { installed at access to } \\
\text { the protected and vital } \\
\text { areas }\end{array}$} & $\begin{array}{l}\text { Emergency power } \\
\text { backup system }\end{array}$ & \\
\hline & $\begin{array}{l}\text { Centralized control to } \\
\text { manage physical }\end{array}$ & \\
\hline $\begin{array}{l}\text { Emergency power } \\
\text { backup system }\end{array}$ & protection system & \\
\hline $\begin{array}{l}\text { Centralized control to } \\
\text { manage physical } \\
\text { protection system }\end{array}$ & & \\
\hline
\end{tabular}

Note. Ministry of Environmental Protection, National Nuclear Safety Administration (NNSA), "Nuclear Facility Physical Protection Guidelines," 2008, HDA501/502. Note that guidelines do not contain an exhaustive list, so the guidelines could apply to facilities that are not explicitly included in the list.

clear zones between them, and reinforced concrete barriers. ${ }^{51}$ There are, for example, detection systems for radioactive material and prohibited items installed at access points to the protected and vital areas at nuclear facilities. To control access to facilities, the plants use mobile barrier gates, metal detecting gates, electric retractable gates, floor-to-ceiling turnstile doors with barcode reading systems, biometric identification systems, and alarm and video monitoring systems at all access points. ${ }^{52}$

The operators for Category I nuclear facilities are required to have hardened central alarm stations, armed forces on duty 24 hours a day, and a "two man and double-lock" rule for the vital area. Also, the licensee is required to set 
up a group and prepare detailed contingency plans to prevent nuclear terrorist acts and nuclear accidents. ${ }^{53}$ Furthermore, the operator of a nuclear facility is required to improve and update its physical protection system and to maintain the system's effectiveness.

Before 1998 the concept of vulnerability analysis of physical protection did not receive attention and there was no evaluation and theoretical analysis about physical protection systems. ${ }^{54}$ Now Chinese facilities are required to conduct in-depth vulnerability assessments with identified vulnerabilities corrected in a timely manner. ${ }^{55}$ Also the operator is required to use technical approaches to strengthen the reliability of the security system, including performance tests of detection and assessment and the use of reliable and compensatory techniques. ${ }^{56}$ China does not, however, conduct realistic "force-on-force" exercises to test the performance of its nuclear security systems. ${ }^{57}$

\section{Material Control and Accountability System}

Based on the 1990 Rules and related IAEA standards, China has established and revised its nuclear materials control and accounting system. In 2008, the NNSA issued new guidelines for "the standard format and content of nuclear facilities safety analysis report on MC\&A." ${ }^{58}$ The MC\&A system must include clear assignments of material balance areas and key measurement points, control of measurement quality, physical inventory of materials, material unaccounted for (MUF) assessment, and recording and reporting system. The licensee must establish nuclear material physical inventory procedures with requirements including conducting complete and strict physical inventories at least once a year and conducting physical inventory for such material as plutonium-239, uranium-233 and HEU at least twice a year. The licensee is required to ensure the record of nuclear material accounting is clear, accurate, systematic, and complete, and maintained at least for five years. If the MUF is more than twice the standard deviation of MUF, then an investigation of the loss would be initiated.

The big challenge for China to have an effective MC\&A system is its reprocessing facilities. In fact, the operation of its pilot reprocessing plant discloses some problems. For example, the amount of wastes produced and the MUF were both very high. ${ }^{59}$ The larger reprocessing facilities that China plans to build with capacities of $200 \mathrm{tHM} /$ year and $800 \mathrm{tHM} /$ year, would be more challenging to effective MC\&A than the small pilot facility. Thus, to establish those reprocessing facilities would increase the risk of theft and increase the security burden for operators.

Unlike nuclear power plants, which have income from market sales of electricity, fuel cycle facilities including the pilot reprocessing plant are currently heavily dependent on government financial support. Those facilities often lack 


\section{Zhang}

enough money to hire better-qualified people and install more and better sensors and equipment for effective MC\&A system. ${ }^{60}$ Given the fact that the risk of insider theft at these bulk processing facilities is higher, these facilities should be required to have effective security systems to control and account for all their materials.

\section{STRENGTHENING CHINA'S NUCLEAR SECURITY}

China could take steps to install a more reliable and effective security system to ensure that all its nuclear weapons, weapon-usable nuclear materials, nuclear facilities, and transporters are secure against threats it is likely to face. The following measures would improve China's existing nuclear security system.

\section{Improving Physical Protection System}

China needs to review, update, and upgrade its requirements, including the DBT, for designing physical protection for the nuclear facilities at military and civilian sectors. The operator must be required to develop and implement security plans that provide effective protection against a DBT that includes the full spectrum of plausible adversaries and tactics, including not just brute force but also deception, and stealth from both insiders and outsiders.

China should update its 1987 Regulations and 1990 Rules regarding nuclear materials control, and issue new strict and clear regulations and rules based on a minimum DBT standard. To ensure the new regulations and rules are effectively implemented for facilities and transporters with nuclear weapons and weapon-usable fissile materials, China would need an effective system of enforcement and a constantly developing and improving nuclear security system that would not stagnate. Just as with nuclear safety, the focus should be on continuous improvement, constantly working to find and fix remaining vulnerabilities and find more effective approaches.

As the newly issued INFCIRC/225/Revision 5 recommends, China should use realistic "force-on-force" exercises to test the performance of its nuclear security systems' ability to detect and defeat intelligent adversaries using asymmetric attacks. The newly established CAEA National Nuclear Security Technology Center, responsible for the construction, management, and operation of China's Center of Excellence on Nuclear Security, is considering conducting such tests at its training site. ${ }^{61}$ However, realistic tests must be carried out at operating facilities and Chinese security experts may lack the experience and capabilities to carry out such tests at actual sites without affecting the safety and security of the nuclear facilities during the tests. ${ }^{62}$ China could learn the practice of "force-on-force" exercises through CAEA and U.S. DOE cooperation. 
For example, Chinese experts could be invited to witness such exercises at U.S. sites as have other countries, including France and Japan.

\section{Improving MC\&A and Reducing Internal Risks}

In order to prevent acquisition of nuclear materials, China needs to improve its MC\&A approach at its bulk processing facilities (e.g., fuel fabrication, reprocessing, and processing of aging fissile materials for weapons). Those facilities are facing major challenges in their shortage of modern equipment, technologies, and related professional personnel rooted in the mainly inadequate financing (unlike nuclear power plants that earn higher profits, fuel cycle facilities are dependent mainly on government support). Nuclear security experts have emphasized that it is far easier for insiders to steal small amounts at a time without anyone noticing at those bulk processing facilities. Nearly all of the seizures of stolen HEU and separated plutonium that have occurred have been of bulk material such as powders, apparently stolen without detection by insiders at bulk processing facilities. ${ }^{63}$ Thus, it is essential for China to take effective MC\&A measures to reduce the chances of insider theft.

The government should make sure these facilities have adequate finance to have modern equipment and technologies and related professional personnel For instance, each facility doing bulk processing of weapons-usable materials should use reliable and accurate measurement methods and equipment for material accounting. The operator must establish an accounting system that will rapidly detect if a significant quantity is removed, be able to locate the removal in time and space, and identify who had access.

The operator, in cooperation with relevant government departments, must have an effective program for personnel reliability screening to strengthen access control. ${ }^{64}$ For example, all personnel with access to vital areas must be subject to drug testing, background checks, physical examination, and psychological or mental fitness tests; these tests should be repeated at specified regular intervals. The license conditions for facility operators should specify that personnel must report suspicious behavior to an official authority; the regulations should require constant surveillance of inner areas when they are occupied using either a two-person surveillance system or a technological surveillance system including devices such as closed circuit television cameras.

\section{International Assurance through Transparency and Cooperation}

China should consider becoming more transparent in order to build confidence in the international community that a robust nuclear security program is in place. Some experts suggest that a nation can make substantial amounts 
of information about its nuclear security conditions public without compromising sensitive information. ${ }^{65}$

China could release details of its nuclear security regulations, as well as general reports on implementation of and compliance with those regulations; share information with others confidentially or publicly about approaches, procedures, regulations, best practices, and lessons learned.

China should allow experts organized by the IAEA to conduct reviews of the country's nuclear security arrangements. These reviews have been found by many other states to be helpful in identifying options to improve nuclear security. China is considering whether to have the International Physical Protection Advisory Service (IPPAS) mission to China. It would be advisable for China to have such a mission soon. The IPPAS missions would review and compare China's physical protection measures with international guidelines and best practices and make recommendations for improvements. Also China should consider inviting other IAEA missions including International Nuclear Security Advisory Service (INSServ) mission and State System for Accountancy and Control (SSAC) Advisory Service.

China could encourage its relevant nuclear security professionals to participate in WINS and other workshops and training that facilitate the identification and sharing of best practices.

China could also host some reviews of its nuclear security arrangements by another country under a bilateral-like agreement or program, such as, expanding China and U.S. cooperation to include security reviews of some facilities beginning with civilian facilities including HEU-fueled reactors and the pilot reprocessing plant while the United States does the same for China.

Further, China and U.S. cooperation should expand to the defense sector that deals with nuclear weapons and most sensitive nuclear materials. Primarily, the two governments should restart the U.S.-China lab-to-lab program that ran from 1995 to 1998 partly to help create an interest in modern security systems in China by demonstrating the advantages of a material protection, control, and accounting system. ${ }^{66}$

\section{NOTES AND REFERENCES}

1. Hui Zhang, "Chapter 7: China," in "Global Fissile Material Report 2010: Balancing the Books: Production and Stocks, Fifth annual report of the International Panel on Fissile Materials, Princeton, N.J. (2011), 97-106. http://fissilematerials.org/ library/gfmr10.pdf $>$. Earlier estimates suggested that the amount of fissile material in China is larger. See David Albright, Frans Berkhout, and William Walker, Plutonium and Highly Enriched Uranium 1996 (New York: Oxford University Press, 1997); David Wright and Lisbeth Gronlund, "Estimating China's Production of Plutonium for Weapons," Science \& Global Security 11 (2003): 61; David Albright and Corey Hinderstein, "Chinese Military Plutonium and Highly Enriched Uranium Inventories," ISIS (30 June 2005). A more recent statement by a former 
Russian official suggests that China has produced 40 tons of weapons-grade uranium and 10 tons of weapons-grade plutonium; see Viktor Yesin, "Tretiy posle SShA i Rossii [Third after the United States and Russia]", Voyenno-promyshlennyy kurier, 2 May 2012, <http://vpk-news.ru/articles/8838> (an English version can be found at <http://www.scribd.com/doc/98667133/YESIN-China-s-Nuclear-Potential $\geq$ ). However, Yesin does not provide any evidence to support his figures.

2. After the Heping plant stopped producing HEU in 1987, it reportedly continued producing LEU for naval fuel. Based on discussions with Chinese nuclear experts, December 2012.

3. Zhang, "Chapter 7: China," op. cit.

4. Hui Zhang, "Nuclear Modernization in China," in "Assuring destruction forever: nuclear weapon modernization around the world," Ray Acheson. ed., Reaching Critical Will (a project of the Women's International League for Peace and Freedom) March 2012; Hui Zhang, "How U.S. Restraint Can Keep China's Nuclear Arsenal Small," Bulletin of the Atomic Scientists 68, 4 (July 13, 2012): 73-82. A different estimate suggests that China has a total of 250 nuclear warheads in 2013 and 240 in 2012. See Stockholm International Peace Research Institute, SIPRI Yearbook 2013: Armaments, Disarmaments and International Security (2013). < http://www.sipri.org/yearbook/2013/ files/SIPRIYB13Summary.pdf $>$. The difference in the estimate used here and that given by SIPRI is explained by the higher number of bombers and some replacement of weapons still counted by SIPRI. There are estimates that claim that China may have 1,600-1,800 warheads (see Yesin, "The Third after the United States and Russia" op. cit.) or even up to 3,000 (see Phillip Karber, "Strategic Implications of China's Underground Great Wall," Asian Arms Control Project of Georgetown University, 26 September $26<$ http://www.fas.org/nuke/guide/china/Karber_UndergroundFacilitiesFull_2011_reduced.pdf $>$. For a critical analysis of these numbers, see Hui Zhang, "The Defensive Nature of China's "Underground Great Wall," Bulletin of the Atomic Scientists, 16 January 2012 and Jeffrey Lewis, "Yesin on China's Nukes," 29 June 2012 $<$ http://lewis.armscontrolwonk.com/archive/5460/yesin-on-chinas-nukes >.

5. Mark Stokes, "China's Nuclear Warhead Storage and Handling System," Report of Project 2049 Institute, 12 March 2010. <http://project2049.net/documents/ chinas_nuclear_warhead_storage_and_handling_system.pdf $>$.

6. Ibid.

7. Ibid.

8. National Progress Report on Nuclear Security of the People's Republic of China, 27 March $2012<$ http://www.china.org.cn/world/2012-03/27/content_24998059.htm>;.

9. Communication received from China Concerning Its Policies Regarding the Management of Plutonium, IAEA INFCIRC/549/Add.7/10, 8 July 2011 <www.iaea.org/ Publications/Documents/Infcircs/2011/infcirc549a7-10.pdf $>$.

10. Communication received from China Concerning Its Policies Regarding the Management of Plutonium IAEA INFCIRC/549/Add.7/12, 26 September 2013, http:// www.iaea.org/Publications/Documents/Infcircs/2013/infcirc549a7-12.pdf.

11. Zhao Zhixiang, China Institute of Atomic Energy "Closed Nuclear Fuel Cycle and Sustainable Development of Nuclear Power in China," presentation at Harvard-Peking University Workshop on Economics of Nuclear Reprocessing, 15 October 2011, Beijing, China. However, it is should be noted that, based on recent discussions with CNNC and CIAE nuclear experts, China may not build both facilities. If China concludes a deal with Areva, then China may not need the 200tHM/year plant.

12. Xu Mi, China Institute of Atomic Energy, "Fast Reactor Development for a Sustainable Nuclear Energy Supply in China," presentation at Harvard-Tsinghua 
University Workshop on Nuclear Energy and Nuclear Security, 14-15 March 2010, Beijing, China.

13. Hui Zhang and Shangui Zhao, "China Moves Cautiously Ahead on Nuclear Energy," Analysis, Bulletin of the Atomic Scientists, 22 April $2013<$ http://thebulletin.org/ china-moves-cautiously-ahead-nuclear-energy >.

14. China's National Defense in 2000, <http://www.china.org.cn/e-white/2000>.

15. Pan Ziqiang, eds., Management of Nuclear and Radiological Terrorism Incidents (in Chinese) (Beijing: Science Press, 2005).

16. Construction on China-U.S. Nuclear Security Center Begins, 29 October 2013, $<$ http://news.xinhuanet.com/english/china/2013-10/29/c_132841259.htm > .

17. Hu Jintao, "Towards Greater Nuclear Security through Cooperation," Statement at the Seoul Nuclear Security Summit, Seoul, 27 March $2012<$ http://www.fmprc. gov.cn/eng/topics/hjtatnsnss/t920822.htm>.

18. Li Baodong, ".Security Council High-level Briefing on Counter-terrorism,"curity Council High-level Briefing on Counter-terrorism," 5 May $2005<$ http://www.chinaun.org/eng/hyyfy/t930746.htm > .

19. Information Office of the State Council, The Diversified Employment of China's Armed Forces, April 2013, Beijing, China <http://news.xinhuanet.com/english/china/ 2013-04/16/c_132312681.htm>.

20. China Foundation for International \& Strategy Studies (CFISS), Combating Nuclear Terrorism-Non-state actors' nuclear proliferation and nuclear security (in Chinese) (Beijing: Social Science Academic Press, 2012) 134-135.

21. Zhu Zhixuan, CAEA, "China's Nuclear Security and International Cooperation," presented at Harvard -Tsinghua Workshop on Nuclear Policies: Nuclear Energy and Nuclear Security, 14-15 March 2010, Beijing, China. CFISS op cit.; Pan, et al., Management of Nuclear and Radiological Terrorism Incidents, op cit.

22. Pan, Management of Nuclear and Radiological Terrorism Incidents, op. cit.,191.

23. CFISS, Combating Nuclear Terrorism-Non-state actors' nuclear proliferation and nuclear security, op. cit., 26-29.

24. Pan, Management of Nuclear and Radiological Terrorism Incidents, op. cit., 191.

25. Pan, Management of Nuclear and Radiological Terrorism Incidents, op. cit., 191.

26. Communications with Chinese nuclear experts in Beijing, March and June 2010, and October 2011.

27. Liu Senling, China Institute of Atomic Energy, "Status of Research on Nuclear Security Technology in CIAE," presented at Harvard-Peking University Workshop on Nuclear Security, 13-14 October 2011, Beijing, China.

28. Pan Ziqiang, "Discussion of Several Issues in Safety Management of Radioactive Sources," Radiation Protection 22, 5, September 2002.

29. Zou Yunhua, "Preventing Nuclear Terrorism: A View from China," Nonproliferation Review 17(2) (2010): 347-363.

30. Ibid.

31. Liu Senling, "Status of research on nuclear security technology in CIAE," op. cit.

32. Communications with Chinese nuclear experts in Beijing, October 2011. 
33. China Nuclear Security: "no[t] one gram missed and no[t] one item disappeared" over last fifty years, Liaowang Xinwen Zhoukan (in Chinese) (Outlook Weeks), 26 March $2012<$ http://www.zhige.net/html/2012/0326/43604.html>.

34. Communications with Chinese nuclear experts, October 2012.

35. Communications with Chinese nuclear experts, December 2012.

36. Tang Dan, Yin Xiangdong, Fang Ni, and Guo Cao, "Physical Protection System and Vulnerability Analysis Program in China," Presentation at the 8th ISODARCO Conference on Arms Control, Beijing, October 2002.

37. NTI Nuclear Materials Security Index: Building a Framework for Assurance, Accountability, and Action, $2012<$ http://www.ntiindex.org/static/pdfs/nti_index final.pdf $>$.

38. Lonnie Moor, "Dealing with the Insider Threat," presented at Workshop on the safety and security of China's nuclear facilities, hosted by Managing the Atom Project of Harvard University, China Arms Control and Disarmament Association and Institute for Nuclear Science and Technology at Peking University, 15-18 January 2013, Shenzhen, China. Also, International Atomic Energy Agency, Preventive and Protective Measures Against Insider Threats (International Atomic Energy Agency, Vienna: 2008). World Institute for Nuclear Security, Managing Internal Threats: A WINS International Best Practice Guide for Your Organization (World Institute for Nuclear Security, Vienna: 2010); Matthew Bunn and Kathryn M. Glynn," Preventing Insider Theft: Lessons from the Casino and Pharmaceutical Industries," Journal of Nuclear Materials Management 41, Spring 2013

39. Pan, Management of Nuclear and Radiological Terrorism Incidents, op. cit. 60-62.

40. Communications with Chinese nuclear experts, January 2013.

41. Liu Tianshu, National Nuclear Safety Administration, "Regulation on Physical Protection for Civilian Nuclear Installations in China," presented at Workshop on the safety and security of China's nuclear facilities, 15-18 January 2013, Shenzhen, China. Tang Yingmao, Peking University, "China's Nuclear Law: Recent Development," presented at Workshop on the safety and security of China's nuclear facilities, 15-18 January 2013, Shenzhen, China.

42. See, e.g., Dean Knox, "Nuclear Security and Nuclear Emergency Response In China," Science and Global Security 20 (2012): 30-63.

43. Regulations for Control of Nuclear Materials of the People's Republic of China, the State Council, 1 June 1987. Chinese version is available at CAEA website $<$ http://www.caea.gov.cn/n16/n1130/77219.html>.

44. Rules for Implementation of the Regulations on Nuclear Materials Control of the People's Republic of China, the National Nuclear Safety Administration, the Ministry of Energy, and the Commission of Science, Technology, and Industry for National Defense, 25 September 1990. Chinese version is available at CAEA website $<$ http://www.caea.gov.cn/n16/n1130/77224.html> .

45. National Nuclear Safety Administration, Nuclear Facility Physical Protection Guidelines, 2008, HDA501/502.

46. Rules for Implementation of the Regulations on Nuclear Materials Control of the People's Republic of China, op. cit.

47. Communications with Chinese nuclear experts on China's nuclear security, October 2011 and November 2012.

48. Pan, Management of Nuclear and Radiological Terrorism Incidents, op. cit.; Li Ganjie, "Nuclear Security: The New Challenges for Security of Nuclear Power 


\section{Zhang}

Plants," presentation at IAEA meeting, $2008<\mathrm{http} / / \mathrm{www}-$ pub.iaea.org $/ \mathrm{mtcd} / \mathrm{meetings/}$ PDFplus/2008/cn168/Presentations/Session3_Li.pdf $>$.

49. Li, "Nuclear Security: "The New Challenges for Security of Nuclear Power Plants," op. cit.

50. Yun Zhou, "The Security Implications of China's Nuclear Energy Expansion," Nonproliferation Review 13 (2006): 253-273.

51. Liu Daming, "Practice of the Physical Protection of Nuclear Materials and Nuclear Facilities in China," Journal of Nuclear Materials Management 4, Summer 2010; Liu Daming, China Institute of Atomic Energy, "China National Nuclear Material Control System," presentation at Harvard-Peking University Workshop on Nuclear Security, 13-14 October 2011, Beijing, China.

52. Zhao Shangui, National Nuclear Safety Administration, "Security Practices in Chinese Enrichment Plants and Reprocessing Facilities," presented at Workshop on the safety and security of China's nuclear facilities, 15-18 January 2013, Shenzhen, China; Communications with nuclear security staff of Daya Bay nuclear power plant, January 2012, Shenzhen, China.

53. National Nuclear Safety Administration, Nuclear Facility Physical Protection Guidelines, op. cit.

54. Tang et al., "Physical Protection System and Vulnerability Analysis Program in China," op. cit.

55. Liu, "Practice of the Physical Protection of Nuclear Materials and Nuclear Facilities in China," op. cit.

56. Liu Daming, China Institute of Atomic Energy, "China National Nuclear Material Control System," presentation at Harvard-Peking University Workshop on Nuclear Security, 13-14 October 2011, Beijing, China

57. Communications with Chinese nuclear experts on China's MPC\&A, October 2011 and January 2013.

58. NNSA guidelines of "the standard format and content of nuclear facilities safety analysis report on MC\&A," HAD 501/06, 2008.

59. Communications with Chinese nuclear experts, January 2013.

60. Communications with Chinese nuclear experts, January 2013.

61. Communications with Chinese nuclear security experts, January 2013.

62. Communications with Chinese nuclear security experts, October 2011.

63. Bunn, Matthew, Eben Harrell and Martin B. Malin, "Progress on Securing Nuclear Weapons and Materials: The Four-Year Effort and Beyond," Project on Managing the Atom, Harvard University (March 2012) http://belfercenter.ksg.harvard. edu/files/Progress_In_The_Four_Year_Effort_web.pdf.

64. Moore, Dealing with the insider threat, op. cit.; IAEA, Preventive and Protective Measures Against Insider Threats, op. cit.; WINS, Managing Internal Threats: A WINS International Best Practice Guide for Your Organization, op. cit.; Bunn and Glynn," Preventing Insider Theft: Lessons from the Casino and Pharmaceutical Industries." op. cit.

65. NTI, "Non-Paper 2: Practical Proposals for Providing International Assurances," <https://www.nti.org/media/pdfs/Non-Paper_2_-_Practical_Proposals_for_Providi ng_International_Assurances.pdf?_=1353439879>, Robert Floyd, "Next Steps on International Assurances," NTI, May 2013 < https://www.nti.org/media/pdfs/Next_Steps_ on_International_Assurances_1.pdf >. 
66. Nancy Prindle, "U.S. China on Nuclear Arms and Nonproliferation: Building on Common Technical Interest," in James Brown, ed., Arms Control Issues for the Twenty-First Century (Albuquerque, NM: SNL Publication, SAND97-2619, 1997); Nathan Busch, "China's Fissile Material Protection, Control, and Accounting: The Case for Renewed Collaboration," Nonproliferation Review, Fall/Winter 2002. The cooperation program was terminated in the aftermath of the 1999 Cox Committee Report and allegations of Chinese espionage at U.S. nuclear weapons laboratories. See, Cox Report at <http://www.house.gov/coxreport/pref/preface.html $>$. Findings of the Cox report have been criticized in China and in the United States. See The Information Office of the State Council of P. R. China, "Facts Speak Louder Than Words and Lies Would Collapse on Themselves," 15 July 1999, http://www.chinaembassy.org/eng/zmgx/zmgx/Political\%20Relationship/t35103.htm; See also, Alastair Iain Johnston, W. K. H. Panofsky, Marco Di Capua, and Lewis R. Franklin, The Cox Committee Report: An Assessment, December 1999, Stanford University http://iisdb.stanford.edu/pubs/10331/cox.pdf. 